\title{
A comparison of fresh, pasta filata, and aged Hispanic cheeses using sensory, chemical, functional, and microbiological assessments
}

\author{
L. A. Jimenez-Maroto, A. Lopez-Hernandez, D. L. Borneman, and S. A. Rankin ${ }^{1}$ \\ Department of Food Science, University of Wisconsin-Madison, 1605 Linden Drive, Madison 53706-1565
}

\begin{abstract}
Anecdotal information suggests that some Hispanic consumers may consider US-made Hispanic cheeses as having a general lack of authenticity compared with those made in their countries of origin. To characterize the potential differences, samples of fresh, pasta filata, and aged Hispanic cheeses were acquired from both the United States (total $\mathrm{n}=39$ ) and countries of origin (total $\mathrm{n}=30$ ) purchased from Mexico, Central America (Costa Rica and El Salvador), and the Caribbean (Puerto Rico). The proximate composition, microbial counts, melt profile, and sensory characteristics were evaluated and compared in country-of-origin cheeses and the US-made counterparts. The presence of Listeria spp. was confirmed for 1 Mexican aged cheese sample and 6 cheese samples from Central America (3 fresh, 2 pasta filata, and 1 aged). The chemical composition, melt profile, and sensory characteristics of fresh and pasta filata US Hispanic cheeses were not significantly different from their Mexican counterparts. Likewise, the chemical composition and melt profile of US aged Hispanic cheeses was not significantly different from the aged Mexican cheeses, but sensory characteristics varied among all aged cheeses. These results demonstrate the similarities and differences among US fresh, pasta filata, and aged Hispanic cheeses relative to their counterparts made in the countries of origin.
\end{abstract}

Key words: Hispanic cheese, sensory, canonical discriminant analysis

\section{INTRODUCTION}

In general, the term "Hispanic cheese" refers to cheeses that originate in the Spanish-speaking countries of North and South America. Hispanic cheeses can be loosely grouped into traditional classifications of fresh,

Received July 13, 2015.

Accepted December 15, 2015.

${ }^{1}$ Corresponding author: sarankin@wisc.edu semi-hard, and hard cheeses based on moisture content, culinary application, and age of the cheese. Fresh cheeses, such as Queso Fresco and Queso Panela, are high in moisture, have a pH of 5.3 to 6.5 (Hnosko et al., 2009), undergo little to no ripening, and consequently have a shelf life of 2 to 3 wk with high susceptibility to microbial contamination and outgrowth. Pasta filata cheeses such as Queso Oaxaca, Queso Asadero, and Quesillo, are soft to semi-hard cheeses with lower moisture content than fresh cheeses, have a $\mathrm{pH}$ of 5.0 to 5.6, and are generally recognized as melting cheeses. Aged cheeses, such as Queso Cotija, Queso Duro, and Queso Añejo, are characterized by their hard texture, low moisture, and high sodium content (Tunick, 2007) with strong flavors and aromas reminiscent of those in Parmesan or Romano cheeses, and are commonly grated or crumbled in culinary applications.

The production of Hispanic cheese varieties in the United States has increased from 96 million pounds in 2001 to over 250 million pounds in 2014 (USDA, 2015). This significant growth is driven by the increased popularity of Hispanic foods in the United States (Packaged Facts, 2012) and by the fact that, with a population of over 52 million, the Hispanic ethnicity is the fastestgrowing consumer segment in the United States (US Census Bureau, 2012). However, despite the increased domestic supply of Hispanic cheese, anecdotal information suggests that Hispanic consumers may consider US-made Hispanic cheeses inauthentic. Consequently, some Hispanic consumers select cheeses imported from their countries of origin, as evidenced by the 34 million pounds of Hispanic cheese imported annually, on average, between 2009 and 2014 (Wisconsin Milk Marketing Board, 2015), or even cheeses manufactured in small, unlicensed facilities that might not fully comply with regulatory standards, thus presenting a potential health risk. This study explored whether specific differences exist in the composition, functionality, flavor, and texture properties of Hispanic cheeses made in the United States compared with those made in their countries of origin with the intention to aid US cheese manufacturers in producing Hispanic cheeses with more authentic character. 


\section{MATERIALS AND METHODS}

\section{Cheese Samples}

Commercial samples $(\sim 1.5 \mathrm{~kg})$ corresponding to different US-made Hispanic fresh (Queso Blanco, $\mathrm{n}=21$ ), pasta filata (Queso Oaxaca, $\mathrm{n}=6$ ), and aged (Queso Cotija, $n=12$ ) cheeses were purchased from stores in different cities of the United States, including Madison and Milwaukee, Wisconsin; Chicago, Illinois; and Los Angeles and San Diego, California. Samples of fresh (Queso Panela, $\mathrm{n}=6$ ), pasta filata (Queso Oaxaca, $\mathrm{n}$ $=6$ ), and aged (Queso Cotija, $\mathrm{n}=3$ ) cheeses made in Mexico were purchased in Hermosillo, Sonora, and $\mathrm{Cu}-$ ernavaca, Morelos. Samples of fresh (Queso Turrialba, $\mathrm{n}=3$ ), pasta filata (Queso Palmito, $\mathrm{n}=3$ ), and aged (Queso Bagaces, $\mathrm{n}=2$, and Queso Duro Viejo, $\mathrm{n}=2$ ) Central American cheeses were purchased in San Jose, Costa Rica, and San Salvador, El Salvador. Samples of fresh (Queso Blanco Fresco, $\mathrm{n}=4$ ) and pasta filata (Queso Oaxaca, $\mathrm{n}=1$ ) Caribbean cheeses were purchased in San Juan, Puerto Rico, but no aged samples were found. All samples were transported in refrigerated containers within $24 \mathrm{~h}$ of purchase and, upon arrival, assigned a random 3-digit reference number and stored at refrigeration temperatures for no longer than $2 \mathrm{wk}$ before analysis. Samples were acquired over a period of 12 mo. It was our intention to secure more imported samples for study but import costs and customs restrictions prevented this endeavor.

\section{Proximate Composition}

All samples were analyzed, in triplicate, for protein and fat contents using AOAC International (2000) methods (methods 991.20 and 933.05, respectively), moisture and $\mathrm{pH}$ as described in Wehr and Frank (2004; methods 15.111 and 15.022 , respectively), and sodium content using a chloride analyzer (M926 Chloride Analyzer, Nelson-Jameson, Marshfield, WI) as described in Johnson and Olson (1985).

\section{Microbiological Analyses}

Cheese samples were analyzed for aerobic plate count, coliform, and yeasts and molds using AOAC International (2000) methods (990.12, 991.14, and 997.02, respectively), heterofermentative lactobacilli following Downes and Ito (2001; method 19.526), and lactic acid bacteria as described in CCFRA (1995; method 14.1). Additionally, cheeses were assessed for the presence of Listeria spp. (Hitchins, 1998), Salmonella spp. (Andrews and Hammack, 1998), and coagulase-positive staphylococci (Bennett and Lancette, 2001), and any samples found positive for any of the 3 type of bacteria were excluded from sensory studies.

\section{Melt Profile}

Melting properties were characterized using a UW Meltmeter (Muthukumarappan, 2001) at the time the samples were evaluated by the descriptive panel. Samples were cut into cylinders $7 \mathrm{~mm}$ in height and 30 $\mathrm{mm}$ in diameter and allowed to stabilize to a temperature of $6^{\circ} \mathrm{C}$ over $3 \mathrm{~h}$; then, the height of the sample was recorded every $3 \mathrm{~s}$ over a period of $15 \mathrm{~m}$. The softening point, flow rate, and degree of flow of each sample were calculated from the melt profile obtained. Each sample was measured in quadruplicate.

\section{Descriptive Sensory Analysis}

Individuals from university staff and the student body ( $\mathrm{n}=13)$ were selected based on availability, interest, and sensory acuity. The panel received $30 \mathrm{~h}$ of training and $10 \mathrm{~h}$ of practice on the Spectrum method (Meilgaard et al., 2007) for appearance, hand texture, mouth texture, and basic taste attributes, and on quantitative descriptive analysis for flavor attributes. Appearance (Table 1) and texture (Table 2 and Table 3) attributes were evaluated using visual, hand, mouth, and residual techniques (Drake et al., 1999; Brown et al., 2003; Meilgaard et al., 2007). Hand firmness anchors were created using commercial putty (Thera-Flex Therapy Putty, Isokinetics Inc., De Queen, AR) with different degrees of resistance. Flavor descriptors (Table 4) were adopted from previous research on Cheddar cheese (Drake et al., 2001) and the Chihuahua cheese lexicon (Van Hekken et al., 2007), and were then expanded during training sessions as panelists identified and defined other attributes.

Cheese samples were prepared $2 \mathrm{~h}$ before evaluation. Cheese was cut into $2-\mathrm{cm}^{3}$ cubes using a cheese slicer (Easy Cheeser N55300A-2, Nemco Inc., Hicksville, $\mathrm{OH})$. Four cubes from each sample were placed in covered plastic containers labeled with random 3-digit codes and stored at $4^{\circ} \mathrm{C}$ until analysis. All evaluations were done at room temperature $\left(21^{\circ} \mathrm{C}\right)$ and the appearance, texture, and flavor references were available to the panelists at all times.

\section{Statistical Analysis}

Statistical differences in proximate and melt profile data were determined by ANOVA using Fisher's least significant difference at $\alpha<0.05$. Sensory data were evaluated using canonical discriminant analysis on the means of each product by region of origin. Flavor 
Table 1. Appearance attributes evaluated, definitions, technique description, and references used

\begin{tabular}{|c|c|c|c|}
\hline Attribute & Definition & Technique & Reference \\
\hline Surface moistness & $\begin{array}{l}\text { Amount of moisture visible } \\
\text { on the surface of the cheese } \\
\text { sample }\end{array}$ & $\begin{array}{l}\text { Observe the sample, without } \\
\text { touching it, observing the } \\
\text { size and distribution of water } \\
\text { pooling on the surface. }\end{array}$ & $\begin{array}{l}1.0=\text { Parmesan }^{7} \\
3.0=\text { Mozzarella } \\
11.5=\text { fresh Mozzarella } \\
13.0=\text { Feta }\end{array}$ \\
\hline Surface oiliness & Amount of surface oil & $\begin{array}{l}\text { Observe the sample, without } \\
\text { touching it, observing for } \\
\text { droplets of oil on the surface of } \\
\text { the cheese and compare with } \\
\text { visual aid. }\end{array}$ & $\begin{array}{l}1.0=\text { Mozzarella heated } 3 \mathrm{~min} \text { at } 55^{\circ} \mathrm{C} \\
4.0=\text { Mozzarella heated } 5 \mathrm{~min} \text { at } 55^{\circ} \mathrm{C} \\
7.0=\text { Mozzarella heated } 7 \mathrm{~min} \text { at } 55^{\circ} \mathrm{C} \\
10.0=\text { Mozzarella heated } 10 \mathrm{~min} \text { at } 55^{\circ} \mathrm{C} \\
13.0=\text { Mozzarella heated } 15 \mathrm{~min} \text { at } 55^{\circ} \mathrm{C}\end{array}$ \\
\hline
\end{tabular}

${ }^{1}$ Philadelphia brand, 226-g block (Kraft Foods North America, Glenview, IL).

${ }^{2}$ Athenos brand, 227-g block (Churny Company Inc., Weyauwega, WI).

${ }^{3}$ Crystal Farms 227-g block; low moisture, part-skim (Crystal Farms, Lake Mills, WI).

${ }^{4}$ Emmi brand, pre-cut (Emmi Inc., Valley Cottage, NY).

${ }^{5}$ Velveeta brand, 907-g loaf (Kraft Foods North America).

${ }^{6}$ Crystal Farms 454-g block. (Crystal Farms).

${ }^{7}$ BelGioioso brand, pre-cut (BelGioioso Cheese Inc., Denmark, WI).

${ }^{8}$ BelGioioso brand, 453-g lump (BelGioioso Cheese Inc.).

descriptors with a score lower than 1.0, the sensory threshold, were excluded from the analysis. Stepwise discriminant analysis (SDA) was used to select the flavor attributes that caused the best discrimination using the forward selection process with a $P$-value to enter of 0.25 (Powers and Ware, 1986). All statistical analyses were done using JMP Pro (version 11.0.0; SAS Institute Inc., Cary, NC).

Table 2. Hand texture attributes evaluated, their definitions, technique description, and references used

\begin{tabular}{|c|c|c|c|}
\hline Attribute & Definition & Technique & Reference \\
\hline $\begin{array}{l}\text { Hand cohesiveness } \\
(\mathrm{HCo})\end{array}$ & $\begin{array}{l}\text { How well the sample holds } \\
\text { together during manipulation }\end{array}$ & $\begin{array}{l}\text { Work the sample between the thumb } \\
\text { and the first two fingers } 5-7 \text { times. } \\
\text { Observe how the sample breaks apart } \\
\text { or stays together. }\end{array}$ & $\begin{array}{l}2.0=\text { Feta } \\
5.0=\text { Emmentaler } \\
7.0=\text { sharp Cheddar } \\
9.0=\text { Mozzarella } \\
14.0=\text { process cheese }\end{array}$ \\
\hline $\begin{array}{l}\text { Oiliness residual } \\
\text { (OilRes) }\end{array}$ & $\begin{array}{l}\text { Amount of oil film left on the } \\
\text { finger after manipulating the } \\
\text { sample }\end{array}$ & $\begin{array}{l}\text { After manipulating the sample, } \\
\text { observe the leftover tactile sensation } \\
\text { left on the fingers. }\end{array}$ & $\begin{array}{l}4.0=\text { Parmesan } \\
7.0=\text { sharp Cheddar } \\
9.0=\text { Muenster } \\
11.0=\text { Mozzarella }\end{array}$ \\
\hline
\end{tabular}

${ }^{1}$ Thera-Flex Therapy Putty, Isokinetics Inc. (De Queen, AR).

${ }^{2}$ Sanford L. P. (Oak Brook, IL).

${ }^{3}$ Velveeta brand, 907-g loaf (Kraft Foods North America, Glenview, IL).

${ }^{4}$ Roundy's brand, 454-g block (Roundy's Supermarkets Inc., Milwaukee, WI). 
Table 3. First chew and chewdown texture attributes evaluated, their definitions, technique description, and references used

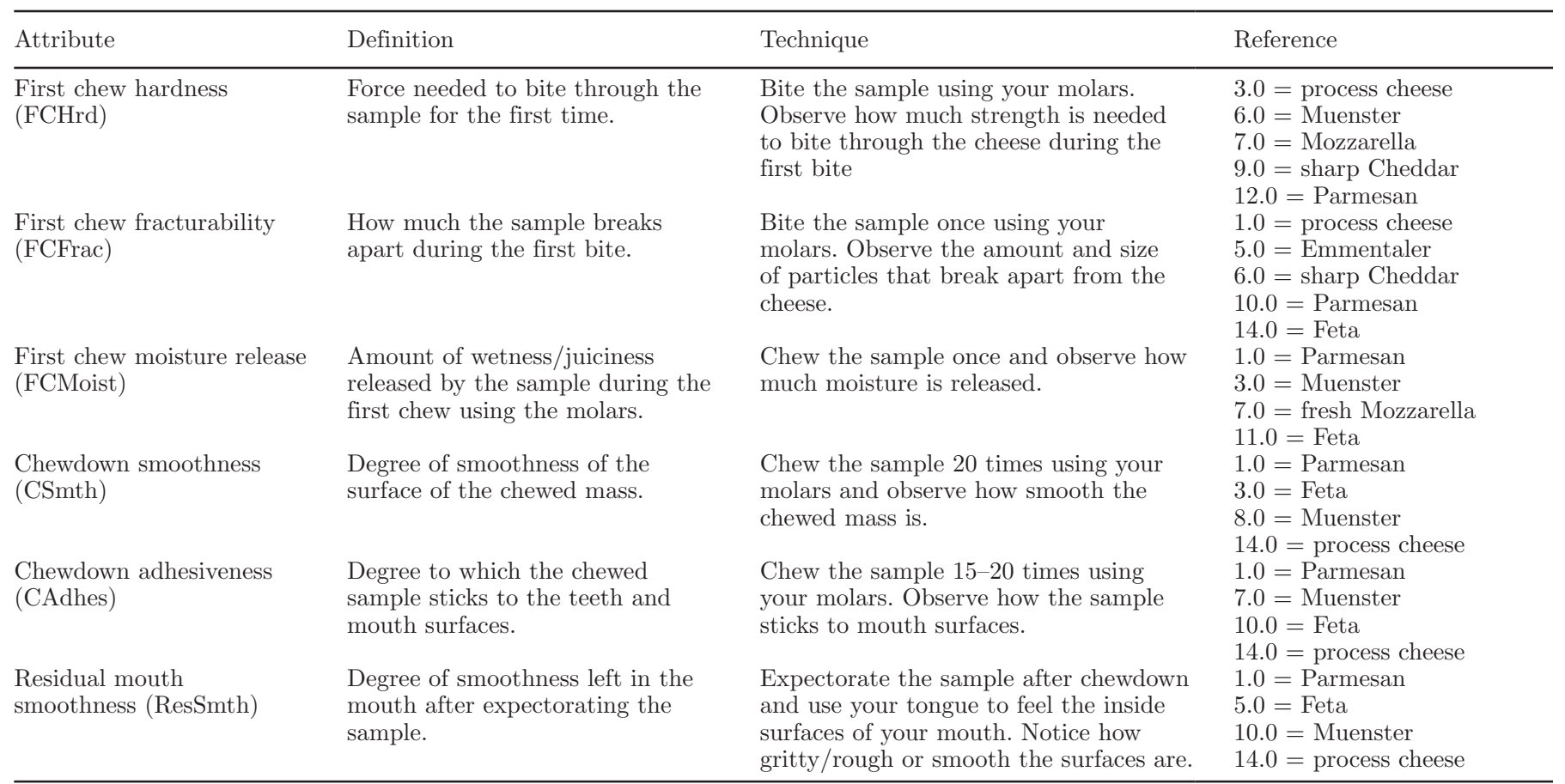

\section{RESULTS AND DISCUSSION}

\section{Proximate Composition}

Composition results are shown in Table 5. Moisture of fresh Central American cheeses (61.1\%) was higher than that of fresh cheeses from Mexico (51.8\%), the Caribbean $(53.8 \%)$, or the United States $(51.6 \%)$, but no difference was found in moisture content between regions for the pasta filata and aged cheeses studied. Mean protein content in fresh cheese samples was highest in Caribbean $(21.5 \%)$ samples, followed by US (19.3\%), Mexican (18.1\%), and Central American (16.5\%) samples, but no difference was found in protein content between regions for the pasta filata and aged cheese samples evaluated. Mean fat contents of fresh cheeses from Mexico (25.1\%) and the United States (23.9\%) were higher than that of fresh cheeses from Central America (19.5\%) and the Caribbean (16.2\%). Mean fat contents of pasta filata cheeses from the United States (25.1\%) were different from that of Mexican (20.9\%) samples, but both were similar to that of Central American (22.4\%) cheeses. For aged cheeses, samples from the United States $(27 \%)$ were higher in fat content than samples from Central America (21.2\%), but both had fat contents similar to samples from Mexico (26.3\%). Sodium chloride content was not statistically different across regions for the types of cheeses studied. Fresh cheeses had sodium contents ranging between 1.3 and 2.3\%, pasta filata cheeses between 1.6 and $1.9 \%$, and aged cheeses between 5.2 and $5.8 \%$. Mean $\mathrm{pH}$ in fresh cheeses was higher for Caribbean samples (5.86), whereas that in cheeses of other regions ranged between 5.3 and 5.5. Pasta filata and aged cheeses had similar $\mathrm{pH}$ values, ranging between 5.22 and 5.34 and between 5.04 and 5.14, respectively.

\section{Microbiological Analyses}

Fresh Hispanic cheese microbial data (Table 6) showed high coliform, coagulase-positive staphylococci, yeast, and mold counts for the Central American samples, as well as positive detection of Listeria spp. For this reason, the sensory analyses of the Central American samples was limited to appearance and tactile perception attributes only. Only a few Mexican, Caribbean, and US-made samples showed unusually elevated counts of coliforms and yeasts in excess of the $500 \mathrm{cfu} / \mathrm{g}$ limit set by Mexican regulations (Dirección General de Normas, 1994).

Pasta filata Hispanic cheese microbial data (Table 7) showed that Central American samples carried high coliform, yeast, and mold counts. Two of the Central American pasta filata samples were also positive for Listeria spp., and thus their sensory evaluation was limited to appearance and hand texture attributes.

Aged Hispanic cheese microbial data (Table 8) showed that one artisan-style Mexican sample tested positive for Listeria spp. and had high counts of coagulase-positive staphylococci. In addition, one of the Central American 
Table 4. Flavor attributes evaluated, their definitions, and references used

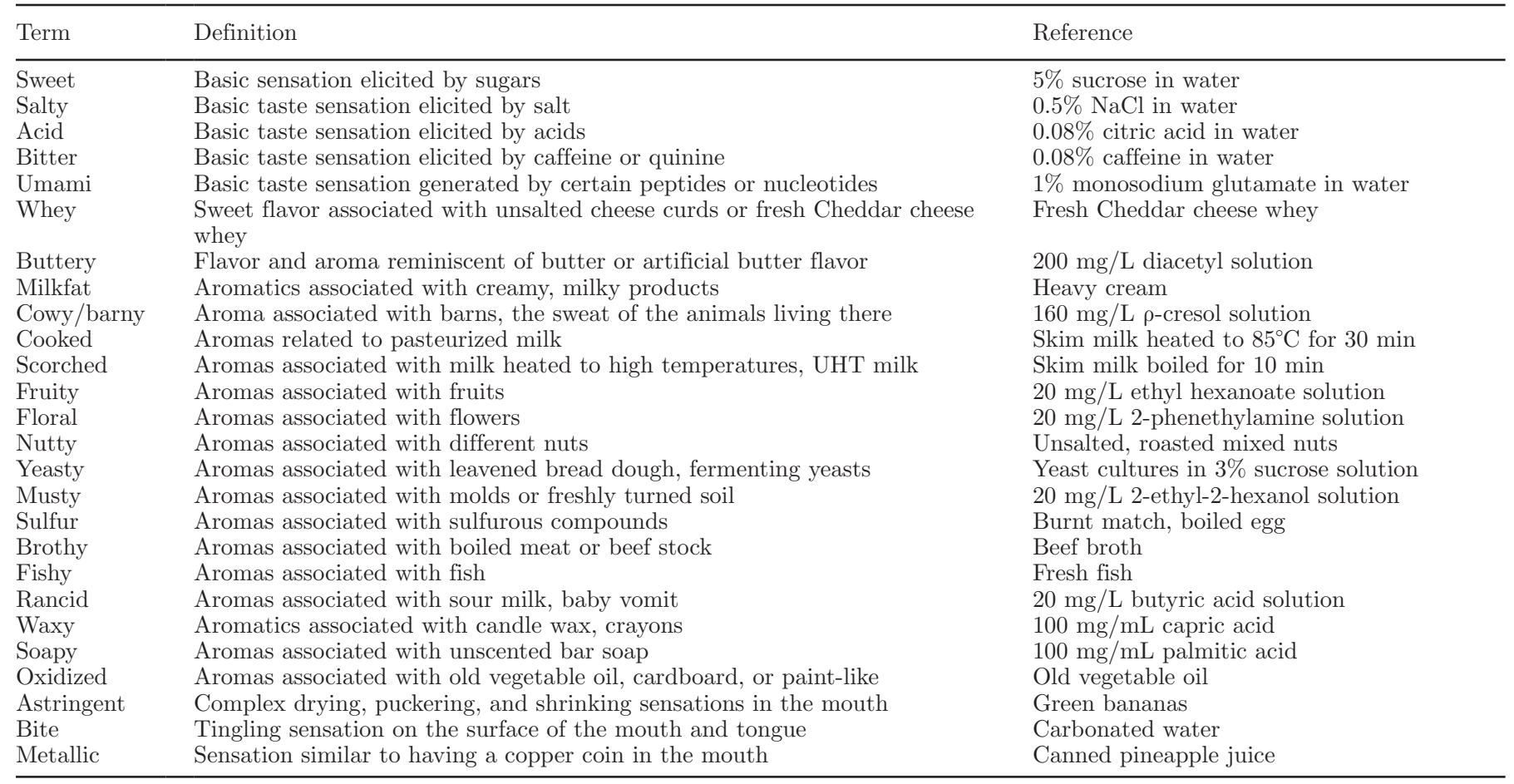

samples showed high coagulase-positive staphylococci and coliform numbers. Due to the high salt, age, and low moisture, it is telling to find such samples with high bacterial counts.

\section{Melt Profile}

Fresh Hispanic cheeses are often regarded as nonmelting cheeses, but the results indicate that this is not necessarily true for all regions studied (Table 9). Cheeses from all regions had a statistically similar softening point. Caribbean samples had a very slow flow rate $(4.2 \mu \mathrm{m} / \mathrm{s})$ and only flowed $22.05 \%$ from their original shape at $60^{\circ} \mathrm{C}$, indicating they are true nonmelting cheeses. The flow rate and degree of flow of Mexican $(11.22 \mu \mathrm{m} / \mathrm{s}$ and $55.77 \%$, respectively) and US (11.79 $\mu \mathrm{m} / \mathrm{s}$ and $54.3 \%$, respectively) cheeses were similar. Central American samples showed a very high flow rate $(20.5 \mu \mathrm{m} / \mathrm{s})$ and degree of flow $(76.21 \%)$, showing a melt character more similar to that of melting cheeses, possibly caused by higher moisture and lower $\mathrm{pH}$ of these samples.

Table 5. Proximate composition of the cheeses studied (mean values with SD in parentheses)

\begin{tabular}{|c|c|c|c|c|c|c|}
\hline Cheese type/region & No. of samples & Moisture (\%) & Protein (\%) & Fat $(\%)$ & Salt $(\mathrm{NaCl} ; \%)$ & $\mathrm{pH}$ \\
\hline \multicolumn{7}{|l|}{ Fresh } \\
\hline Caribbean & 4 & $53.8(5.4)^{\mathrm{b}}$ & $21.5(4.5)^{\mathrm{a}}$ & $16.6(2.0)^{\mathrm{b}}$ & $2.2(0.6)^{\mathrm{a}}$ & $5.86(0.32)^{\mathrm{b}}$ \\
\hline Central America & 3 & $61.1(1.5)^{\mathrm{a}}$ & $16.5(0.5)^{\mathrm{c}}$ & $19.5(2.0)^{\mathrm{b}}$ & $1.3(0.3)^{\mathrm{a}}$ & $5.32(0.17)^{\mathrm{a}}$ \\
\hline United States & 21 & $51.6(3.8)^{\mathrm{b}}$ & $19.3(1.3)^{\mathrm{ab}}$ & $23.9(3.3)^{\mathrm{a}}$ & $2.3(1.3)^{\mathrm{a}}$ & $5.42(0.11)^{\mathrm{a}}$ \\
\hline \multicolumn{7}{|l|}{ Pasta filata } \\
\hline Caribbean $^{1}$ & 1 & 52.0 & 23.7 & 18.5 & 1.8 & 5.33 \\
\hline United Sates & 6 & $47.8(2.5)^{\mathrm{a}}$ & $25.0(1.8)^{\mathrm{a}}$ & $25.1(2.5)^{\mathrm{a}}$ & $1.8(0.6)^{\mathrm{a}}$ & $5.22(0.12)^{\mathrm{a}}$ \\
\hline \multicolumn{7}{|l|}{ Aged } \\
\hline Central America & 4 & $40.9(3.6)^{\mathrm{a}}$ & $23.0(2.3)^{\mathrm{a}}$ & $21.2(1.5)^{\mathrm{b}}$ & $5.6(2.7)^{\mathrm{a}}$ & $5.14(0.06)^{\mathrm{a}}$ \\
\hline Mexico & 3 & $43.8(1.6)^{\mathrm{a}}$ & $21.0(1.0)^{\mathrm{a}}$ & $26.3(1.0)^{\mathrm{ab}}$ & $5.8(1.3)^{\mathrm{a}}$ & $5.04(0.05)^{\mathrm{a}}$ \\
\hline United States & 12 & $41.4(2.4)^{\mathrm{a}}$ & $23.9(2.0)^{\mathrm{a}}$ & $27.0(3.7)^{\mathrm{a}}$ & $5.2(1.6)^{\mathrm{a}}$ & $5.07(0.13)^{\mathrm{a}}$ \\
\hline
\end{tabular}

\footnotetext{
${ }^{a-c}$ Means within a column and a cheese type with different superscripts differ $(P<0.05)$.
}

${ }^{1}$ Not enough samples to perform statistical analysis; individual sample result reported. 


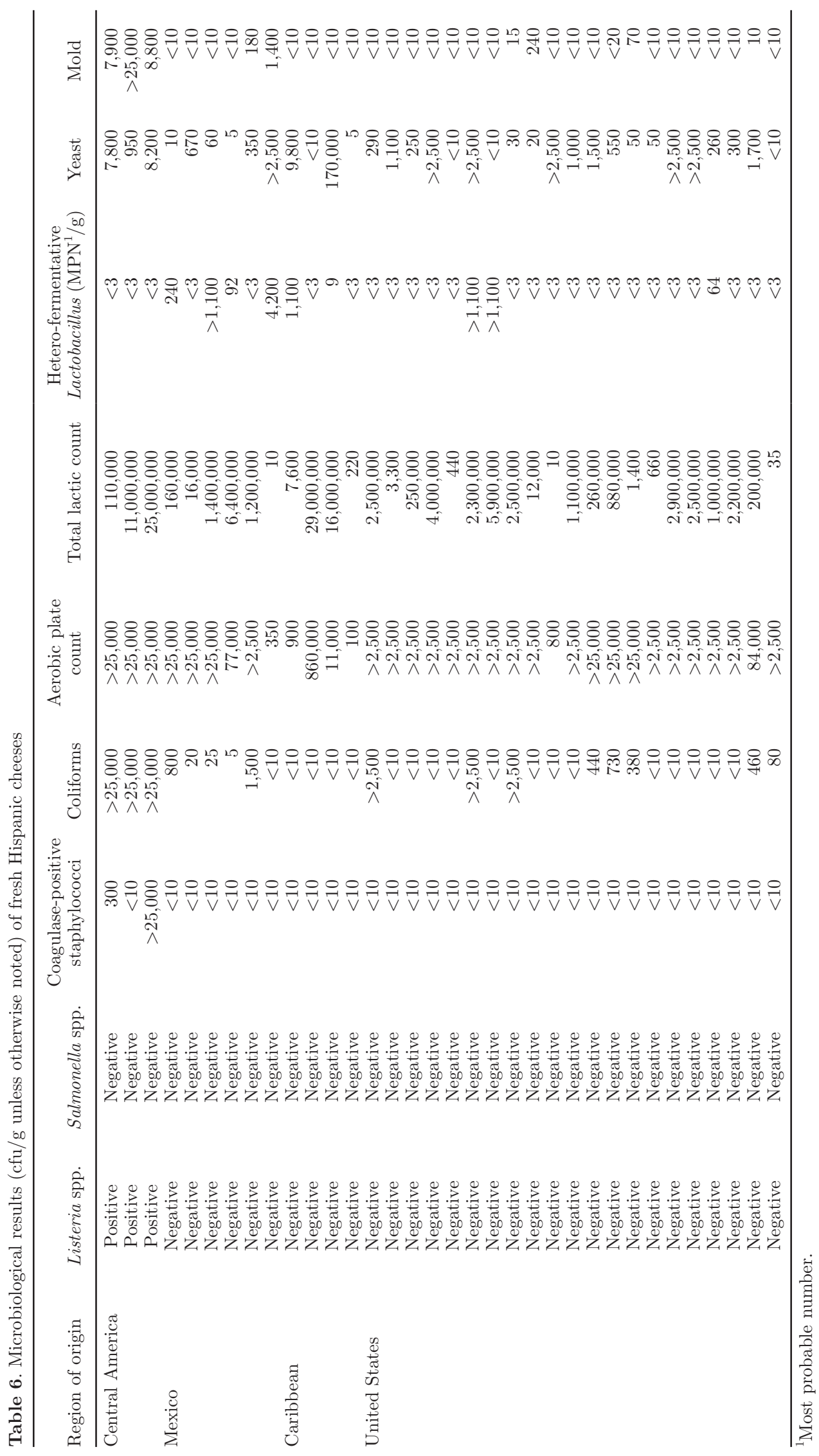



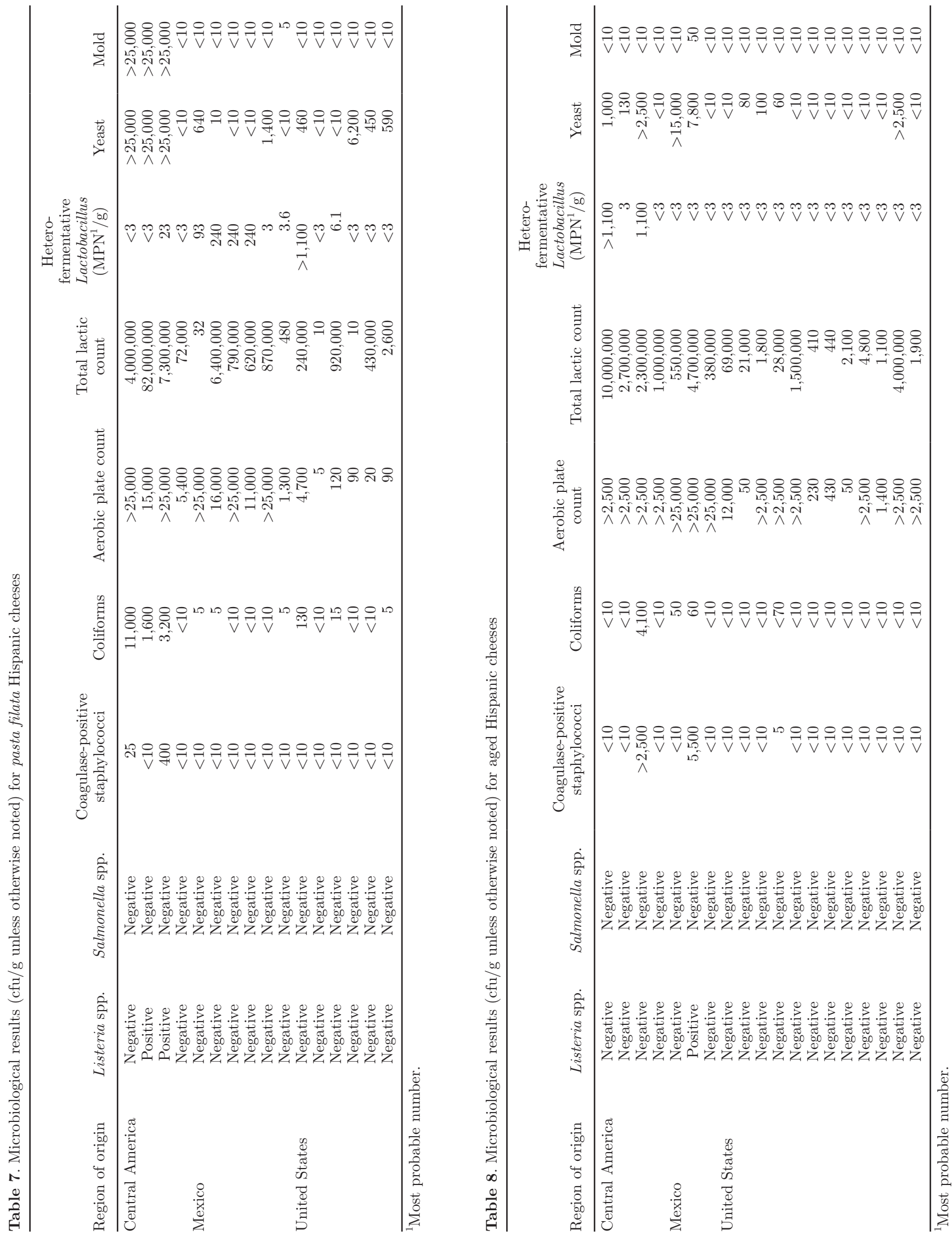
Table 9. Melt characteristics of Hispanic cheeses (mean values with SD in parentheses)

\begin{tabular}{lcccc}
\hline Cheese type/region & $\begin{array}{c}\text { No. of } \\
\text { samples }\end{array}$ & $\begin{array}{c}\text { Softening } \\
\text { point }\left({ }^{\circ} \mathrm{C}\right)\end{array}$ & $\begin{array}{c}\text { Flow rate } \\
(\mu \mathrm{m} / \mathrm{s})\end{array}$ & $\begin{array}{c}\text { Degree of flow } \\
\left(\% \text { at } 60^{\circ} \mathrm{C}\right)\end{array}$ \\
\hline $\begin{array}{l}\text { Fresh } \\
\text { Caribbean }\end{array}$ & 4 & $43.3(7.7)^{\mathrm{a}}$ & $4.2(2.4)^{\mathrm{c}}$ & $22.0(17.9)^{\mathrm{c}}$ \\
$\quad \begin{array}{l}\text { Central America } \\
\text { Mexico }\end{array}$ & 3 & $39.7(6.0)^{\mathrm{a}}$ & $20.5(11.9)^{\mathrm{a}}$ & $76.2(23.9)^{\mathrm{a}}$ \\
$\quad \begin{array}{l}\text { United States } \\
\text { Pasta filata }\end{array}$ & 6 & $44.3(2.6)^{\mathrm{a}}$ & $11.2(4.3)^{\mathrm{bc}}$ & $55.8(17.2)^{\mathrm{ab}}$ \\
$\quad$ Caribbean & 21 & $44.5(2.1)^{\mathrm{a}}$ & $11.8(5.1)^{\mathrm{b}}$ & $54.3(16.5)^{\mathrm{b}}$ \\
$\quad \begin{array}{l}\text { Central America } \\
\text { Mexico }\end{array}$ & 1 & 39.5 & 38.9 & 91.6 \\
$\quad \begin{array}{l}\text { United States } \\
\text { Aged }\end{array}$ & 3 & $44.4(2.9)^{\mathrm{a}}$ & $31.5(2.7)^{\mathrm{a}}$ & $86.1(2.0)^{\mathrm{a}}$ \\
$\quad$ Central America & 6 & $41.6(3.5)^{\mathrm{a}}$ & $30.6(4.3)^{\mathrm{a}}$ & $84.9(3.8)^{\mathrm{ab}}$ \\
$\quad \begin{array}{l}\text { Mexico } \\
\text { United States }\end{array}$ & 6 & $40.5(3.0)^{\mathrm{a}}$ & $27.6(5.8)^{\mathrm{a}}$ & $80.1(4.4)^{\mathrm{b}}$ \\
\hline
\end{tabular}

${ }^{\mathrm{a}-\mathrm{c}}$ Means within a column and a cheese type with different superscripts differ $(P<0.05)$.

${ }^{1}$ Not enough samples to perform statistical analysis; individual sample result reported.

${ }^{2}$ Due to cheese hardness and brittleness, 4 US-made aged cheese samples could not be sampled for the melt profile analysis.

Table 10. Mean scores for sensory attributes by region for fresh Hispanic cheeses

\begin{tabular}{|c|c|c|c|c|c|c|c|}
\hline Attribute & \multicolumn{4}{|c|}{ Mean descriptive score by region } & \multicolumn{3}{|c|}{ Stepwise process ${ }^{1}$} \\
\hline \multicolumn{8}{|l|}{ Appearance } \\
\hline Moistness & $5.4^{\mathrm{b}}$ & $12.5^{\mathrm{a}}$ & $11.0^{\mathrm{a}}$ & $10.0^{\mathrm{a}}$ & 10.23 & 0.00 & Yes \\
\hline Oiliness & 3.0 & 2.1 & 3.1 & 2.9 & 0.83 & 0.49 & No \\
\hline \multicolumn{8}{|l|}{ Hand texture ${ }^{2}$} \\
\hline $\mathrm{HCr}$ & 11.7 & 11.8 & 10.0 & 10.5 & 2.65 & 0.07 & Yes \\
\hline \multirow{2}{*}{\multicolumn{8}{|c|}{$\begin{array}{l}\text { OilRes } \\
\text { Mouth texture }\end{array}$}} \\
\hline & & & & & & & \\
\hline FCHrd & $6.5^{\mathrm{a}}$ & & $3.6^{\mathrm{b}}$ & $5.1^{\mathrm{ab}}$ & 1.01 & 0.38 & No \\
\hline FCFrac & 8.9 & & 9.2 & 9.3 & 0.14 & 0.87 & No \\
\hline FCMoist & $4.8^{\mathrm{b}}$ & & $8.0^{\mathrm{a}}$ & $7.0^{\mathrm{a}}$ & 3.83 & 0.03 & Yes \\
\hline Salty & $3.1^{\mathrm{ab}}$ & & $2.5^{\mathrm{b}}$ & $4.5^{\mathrm{a}}$ & 5.22 & 0.01 & Yes \\
\hline Acid & 1.5 & & 1.8 & 2.0 & 0.61 & 0.55 & No \\
\hline Bitter & 1.9 & & 2.0 & $1.9^{\mathrm{a}}$ & 0.78 & 0.47 & No \\
\hline Whey & $2.0^{\mathrm{b}}$ & & $3.0^{\mathrm{a}}$ & $3.1^{\mathrm{a}}$ & 0.50 & 0.61 & No \\
\hline Buttery & $0.6^{\mathrm{b}}$ & & $1.6^{\mathrm{a}}$ & $2.0^{\mathrm{a}}$ & 2.84 & 0.08 & Yes \\
\hline Milkfat & 2.3 & & 2.8 & 3.1 & 3.99 & 0.03 & Yes \\
\hline Cowy/Barny & 1.9 & & 1.9 & 1.7 & 0.38 & 0.69 & No \\
\hline Cooked & 1.9 & & 2.2 & 2.4 & 0.18 & 0.84 & No \\
\hline Scorched & $1.6^{\mathrm{b}}$ & & $0.2^{\mathrm{a}}$ & $0.5^{\mathrm{a}}$ & 6.06 & 0.01 & Yes \\
\hline Oxidized & 2.6 & & 2.6 & 2.3 & 1.05 & 0.36 & No \\
\hline
\end{tabular}

\footnotetext{
${ }^{\mathrm{a}, \mathrm{b}}$ Means within a row with different superscripts are significantly different.
}

${ }^{1}$ The $\mathrm{F}$ ratio and $P$-value of the forward stepwise discriminant analysis (SDA) indicating discriminating attributes with $P<0.25$ entered into the canonical discriminant analysis (CDA) of fresh Hispanic cheeses.

${ }^{2}$ Defined in Table 2 .

${ }^{3}$ Defined in Table 3 . 
Pasta filata Hispanic cheeses showed similar melting characteristics between regions, with only a significant difference found in the degree of flow at $60^{\circ} \mathrm{C}$ between Central American (86.09\%) and US-made samples

Appearance, Fresh Cheese

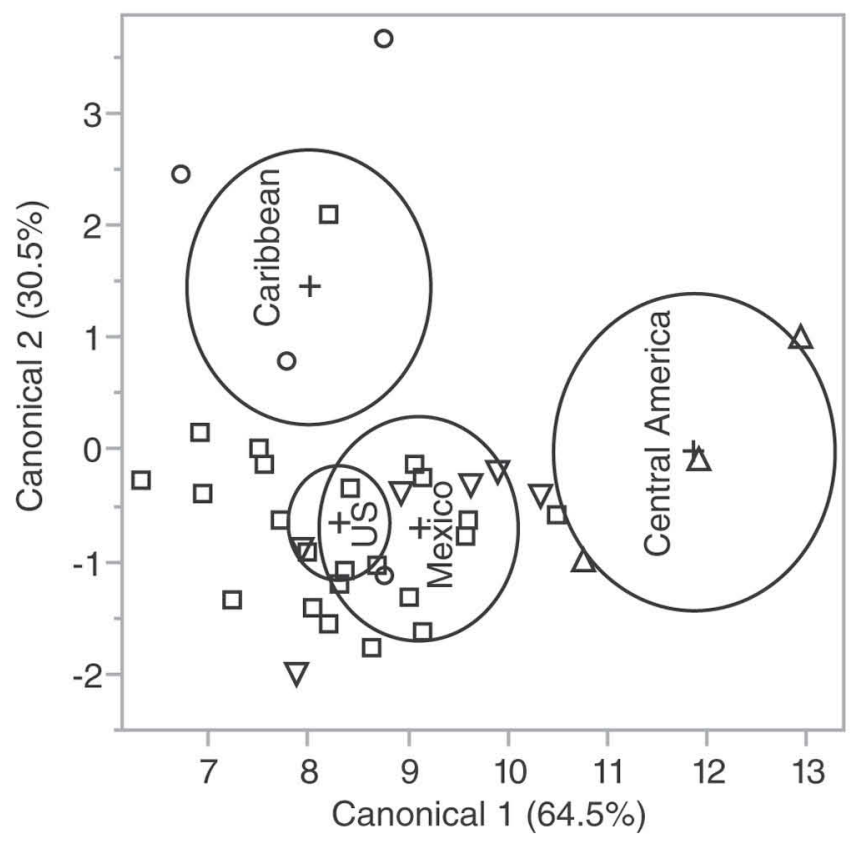

Mouth Texture, Fresh Cheese

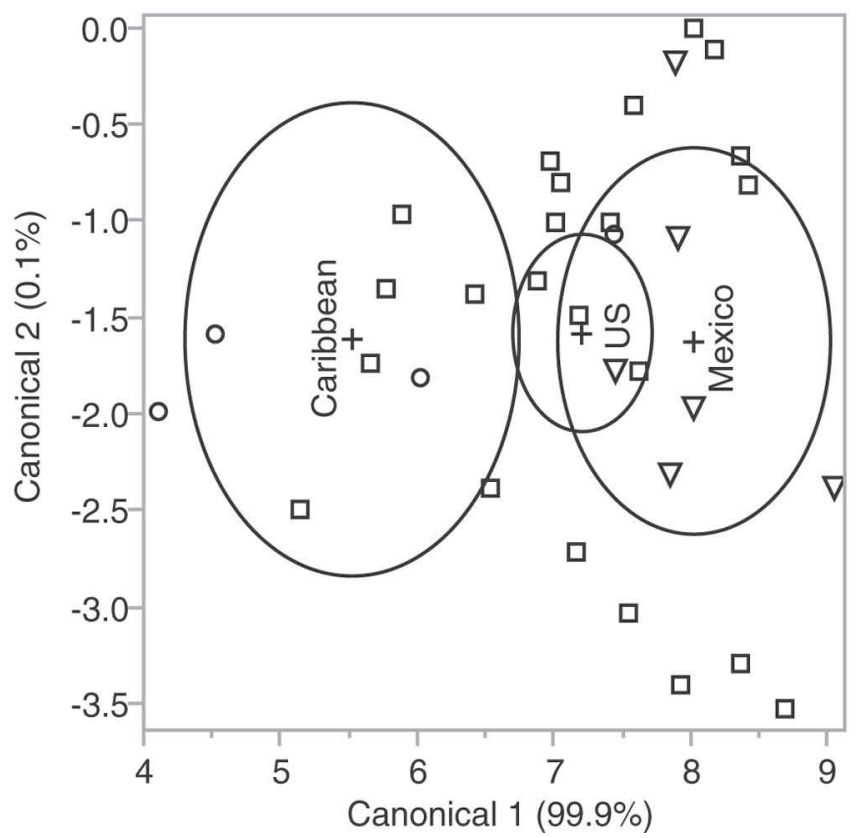

(80.06\%). Overall, the pasta filata samples showed characteristics expected of melting cheeses.

Aged Hispanic cheeses exhibited melting profiles expected of ripened, low-moisture cheeses. Central

\section{Hand Texture, Fresh Cheese}

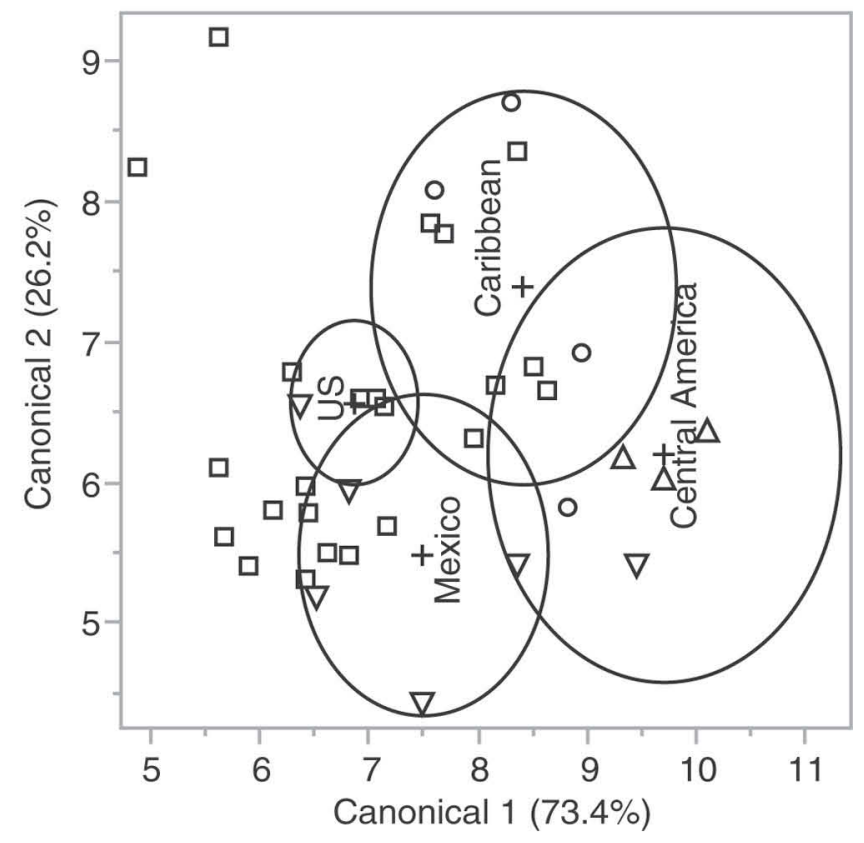

Flavor, Fresh Cheese

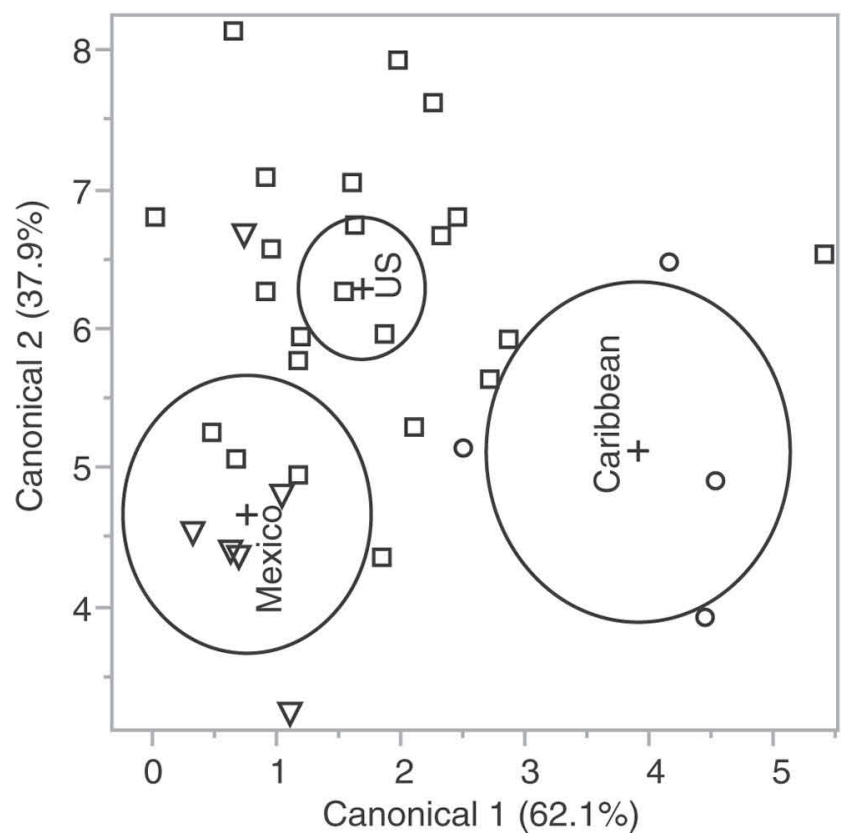

Figure 1. Canonical plots of fresh Hispanic cheeses by region based on appearance, hand texture, mouth texture, and flavor attributes. The circles represent the $95 \%$ confidence region to contain the true mean of the region. Samples represented are the Caribbean $(\bigcirc)$, Central America $(\Delta)$, Mexico $(\nabla)$, and the United States $(\square)$. 
American samples had a significantly lower softening point $\left(39.5^{\circ} \mathrm{C}\right)$ compared with the Mexican $\left(53^{\circ} \mathrm{C}\right)$ and US-made samples $\left(51.3^{\circ} \mathrm{C}\right)$. Yet, despite softening at a lower temperature, Central American samples had a slower flow rate $(2.49 \mu \mathrm{m} / \mathrm{s})$ and final degree of flow $(13.7 \%)$ than the Mexican $(6.42 \mu \mathrm{m} / \mathrm{s}, 34.07 \%$, respectively) and US-made $(6.41 \mu \mathrm{m} / \mathrm{s}, 33.09 \%$, respectively $)$ samples. In total, 4 US-made and 2 Central American aged cheese samples, because of cheese hardness and brittleness, could not be sampled for the melt profile analysis.

\section{Sensory Analysis}

For fresh Hispanic cheeses, the SDA identified the attributes shown in Table 10 as the attributes that cause the most discrimination. These attributes were used to generate the canonical discriminant analysis plots in Figure 1. For appearance, the overlapping canonical ellipses for US and Mexico samples indicate that they shared visual characteristics, whereas the Caribbean and Central American samples were distinct. Sensory data suggest that this is due to color differences, with lighter colors in the US (3.5) and Mexican (3.9) samples and darker colors in the Caribbean (5.6) and Central American (6.0) samples. Furthermore, surface moistness was lower for Caribbean samples (5.4) than for cheeses from the other regions, which ranged between 10.0 and 12.5. The hand texture plot shows high overlap between regions, with only the US and Central American regions being distinct, probably due to the higher springiness recorded for Central American samples compared with US samples. The mouth texture plot shows overlapping of the US region with Caribbean and Mexican regions, but no overlapping between the latter two. Differences were caused by the Caribbean samples having higher first chew hardness (FCHrd; 6.5), but lower first chew moisture release (FCMoist; 4.8) and chewdown adhesiveness (CAdhes; 6.1) than Mexican (3.6, 8.0, and 7.6, respectively) and US (5.1, 7.0, and 7.3 , respectively) samples. The flavor plot shows the most difference, with no overlapping between samples, which the sen-

Table 11. Mean scores for sensory attributes by region for pasta filata Hispanic cheeses

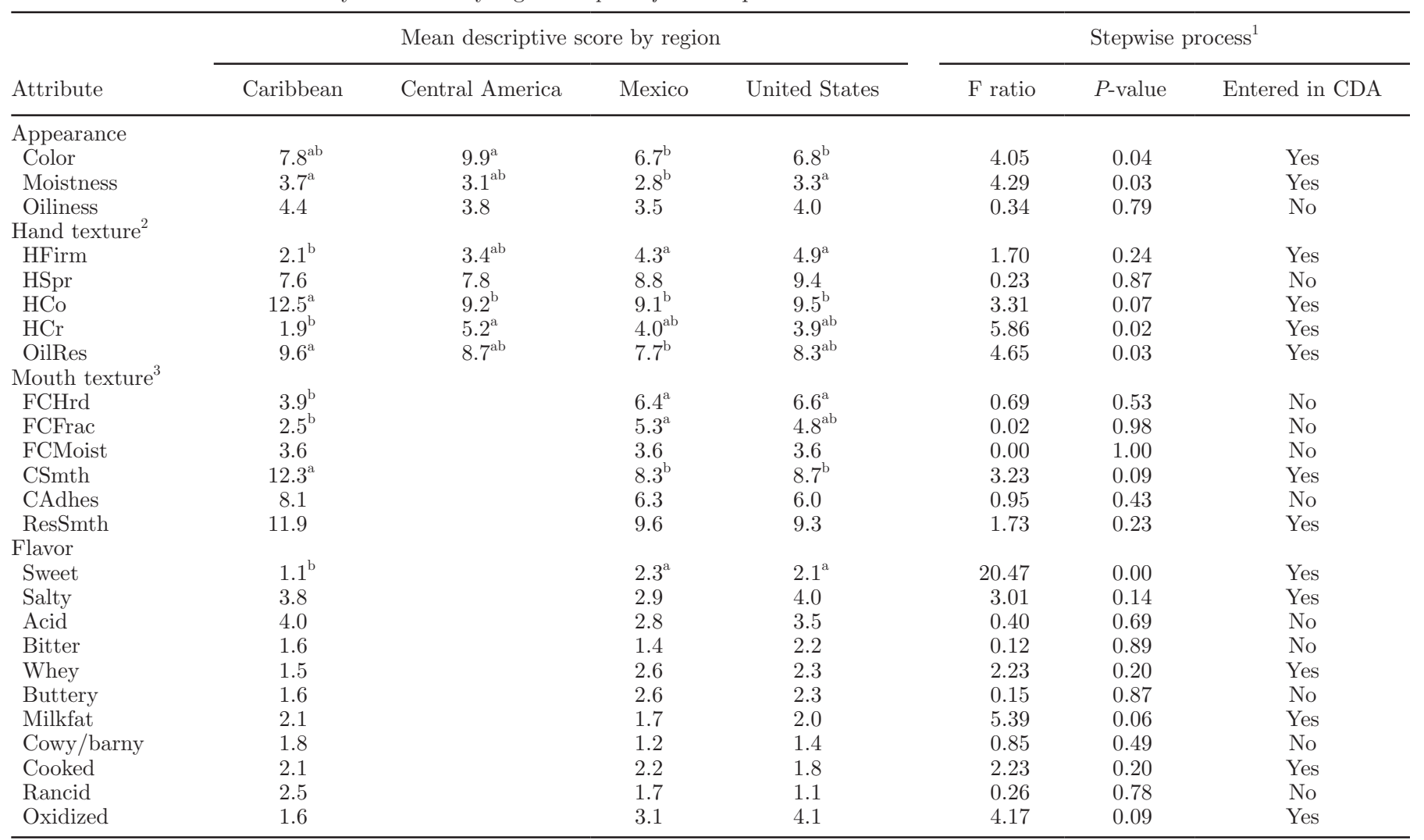

\footnotetext{
${ }^{\mathrm{a}, \mathrm{b}}$ Means within a row with different superscripts are significantly different.
}

${ }^{1}$ The $\mathrm{F}$ ratio and $P$-value of the forward stepwise discriminant analysis (SDA) indicating discriminating attributes with $P<0.25$ entered into the canonical discriminant analysis (CDA) of fresh Hispanic cheeses.

${ }^{2}$ Defined in Table 2 .

${ }^{3}$ Defined in Table 3 . 
Appearance, Pasta Filata Cheese

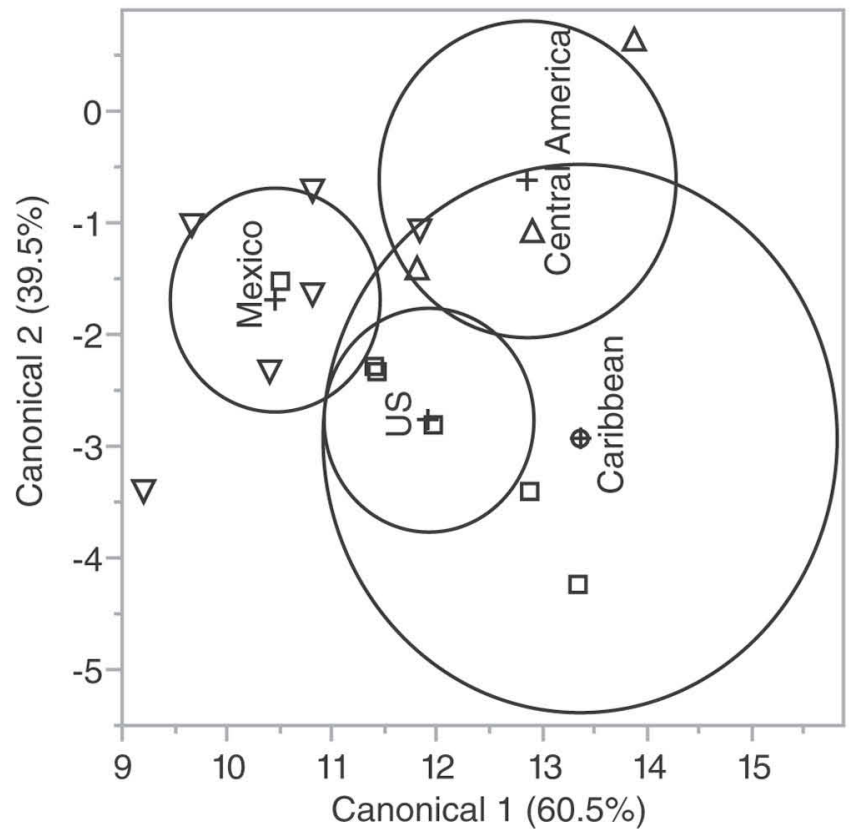

Mouth Texture, Plasta Filata Cheese

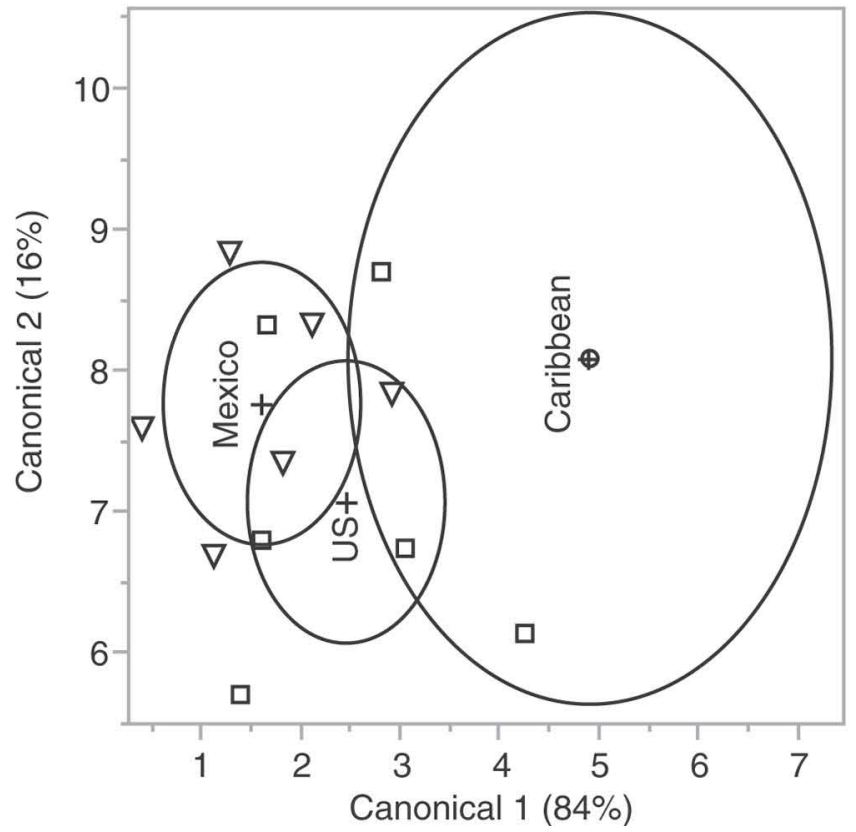

Hand Texture, Pasta Filata Cheese

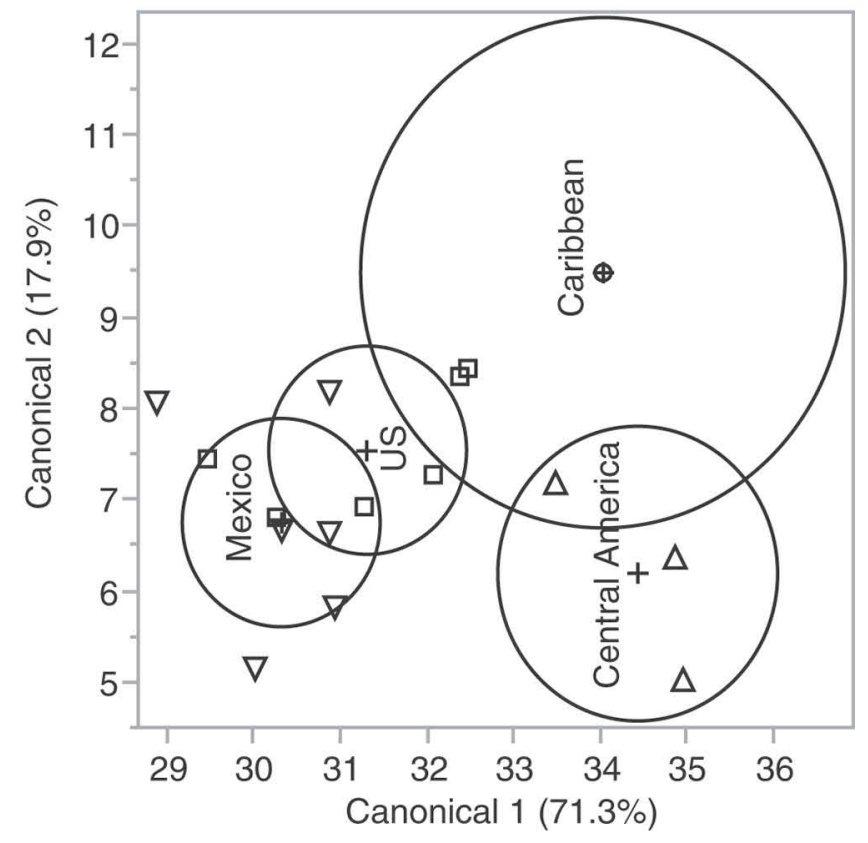

Flavor, Pasta Filata Cheese

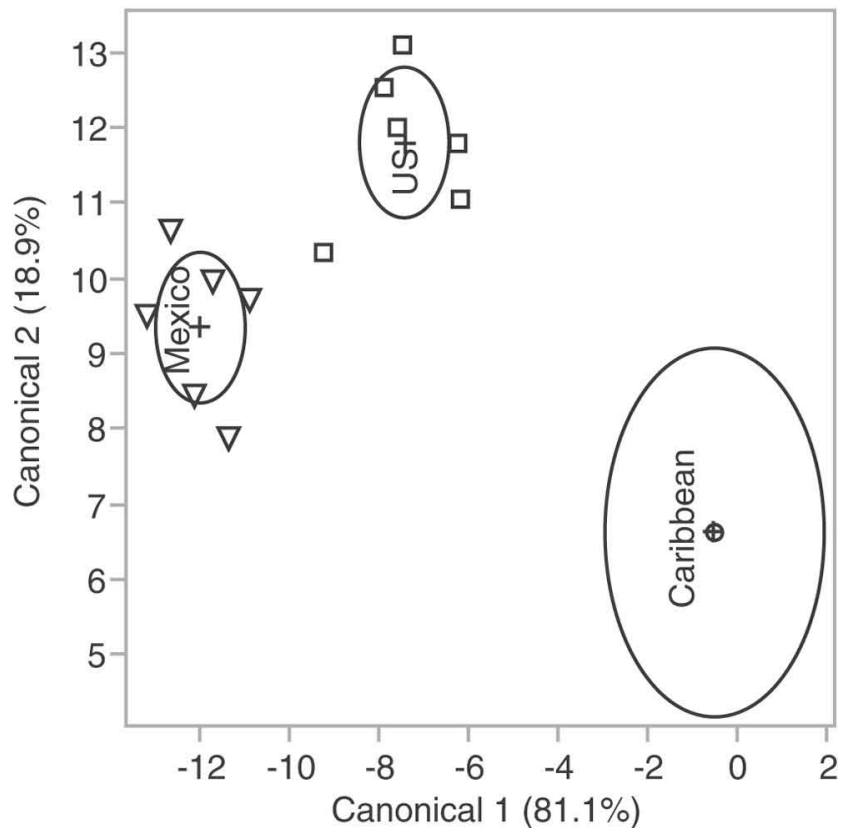

Figure 2. Canonical plots of pasta filata Hispanic cheeses by region based on appearance, hand texture, mouth texture, and flavor attributes. The circles represent the $95 \%$ confidence region to contain the true mean of the region. Samples represented are the Caribbean $(\bigcirc)$, Central America $(\Delta)$, Mexico $(\nabla)$, and the United States $(\square)$.

sory scores suggest is due to the US samples having higher salt and buttery scores and lower scorched scores than samples from the other 2 regions.

For pasta filata cheeses, the SDA selected the attributes shown in Table 11, which were used to generate the plots in Figure 2. The appearance plot shows the US ellipse overlapping all other regions, due to those samples sharing similar lower color scores with Mexican samples but higher surface moistness scores with Caribbean and Central American samples. The hand 
Table 12. Mean scores for sensory attributes by region for aged Hispanic cheeses

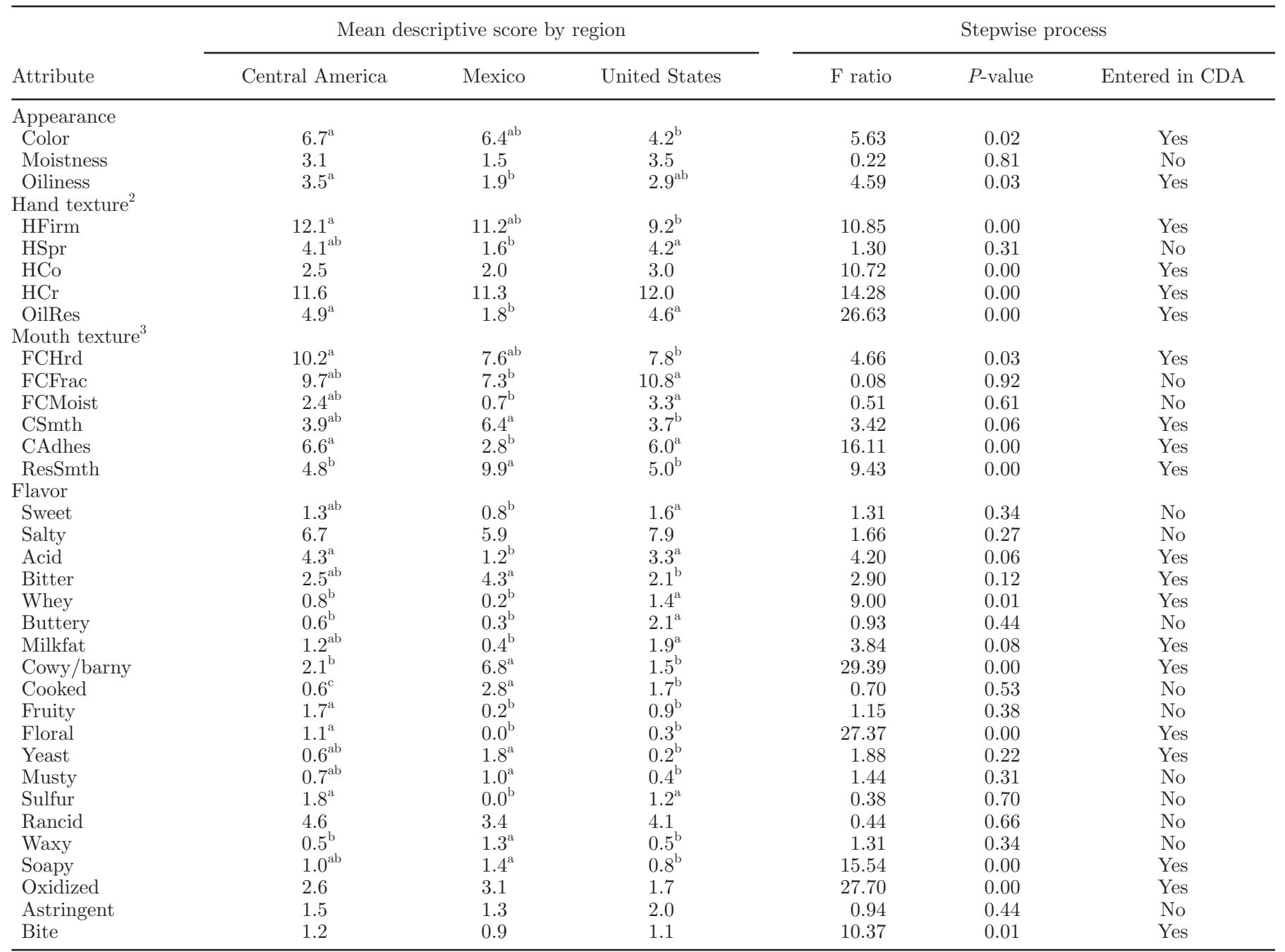

\footnotetext{
${ }^{\mathrm{a}, \mathrm{b}}$ Means within a row with different superscripts are significantly different.
}

${ }^{1}$ The $\mathrm{F}$ ratio and $P$-value of the forward stepwise discriminant analysis (SDA) indicating discriminating attributes with $P<0.25$ entered into the canonical discriminant analysis (CDA) of fresh Hispanic cheeses.

${ }^{2}$ Defined in Table 2.

${ }^{3}$ Defined in Table 3 .

texture plot shows US samples overlapping the Mexican and Caribbean ellipses but separate from the Central American ellipse, which the sensory data suggest is caused primarily by the Central American samples having much higher hand crumbliness ( $\mathrm{HCr}$ ) scores than the other regions. The mouth texture plot shows all ellipses overlapping, indicating that the relevant attributes caused minor discrimination. The flavor plot showed no overlapping ellipses, and the sensory data suggest that this might be caused primarily by the level of sweetness between the samples, but also by higher salt and oxidized scores of the US samples.

For aged cheeses, the SDA-selected attributes are shown in Table 12 and used to generate the plots in Figure 3. The appearance plot shows the US ellipse overlapping with the Central America ellipse but distinct from the Mexican ellipse; this was primarily driven by differences in color and surface oiliness. The hand texture plot shows the ellipses of all regions being separate, with sensory data suggesting that the largest difference was caused by the US samples scoring lower in hand firmness (HFirm) than the other 2 regions. The mouth texture plot also shows no overlapping ellipses, and the sensory data suggest that to make the US samples more similar to Mexican samples, the chewdown smoothness (CSmth) and residual smoothness (ResSmth) would need to be increased, whereas the chewdown adhesiveness (CAdhes) would needs to be lowered, whereas to make them more similar to Central American samples, the first chew hardness 


\section{Appearance, Aged Cheese}

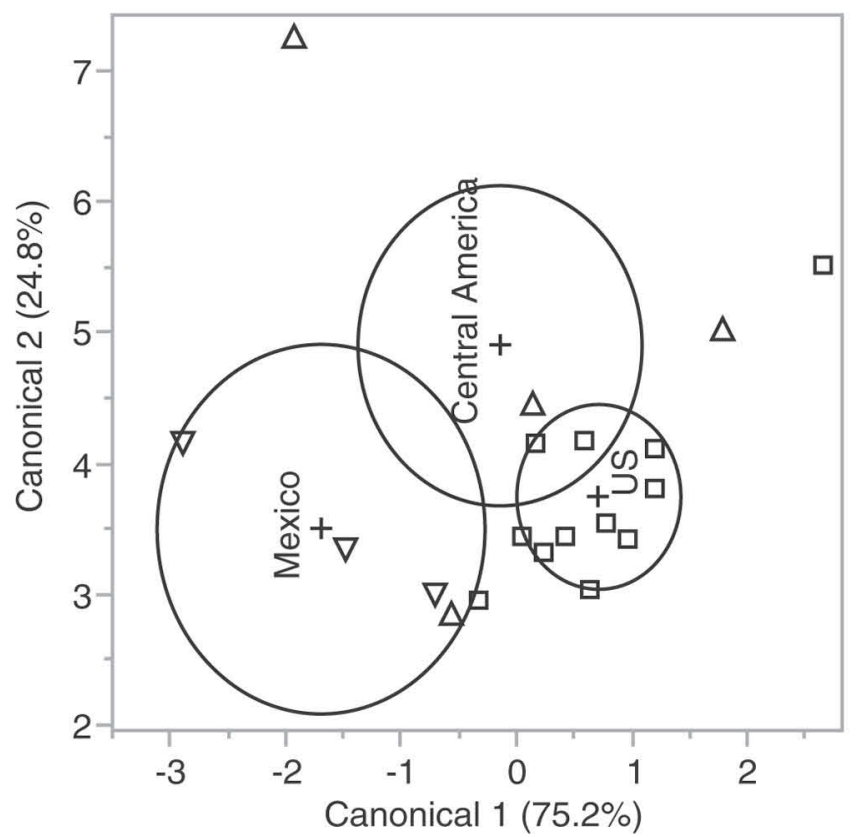

Mouth Texture, Aged Cheese

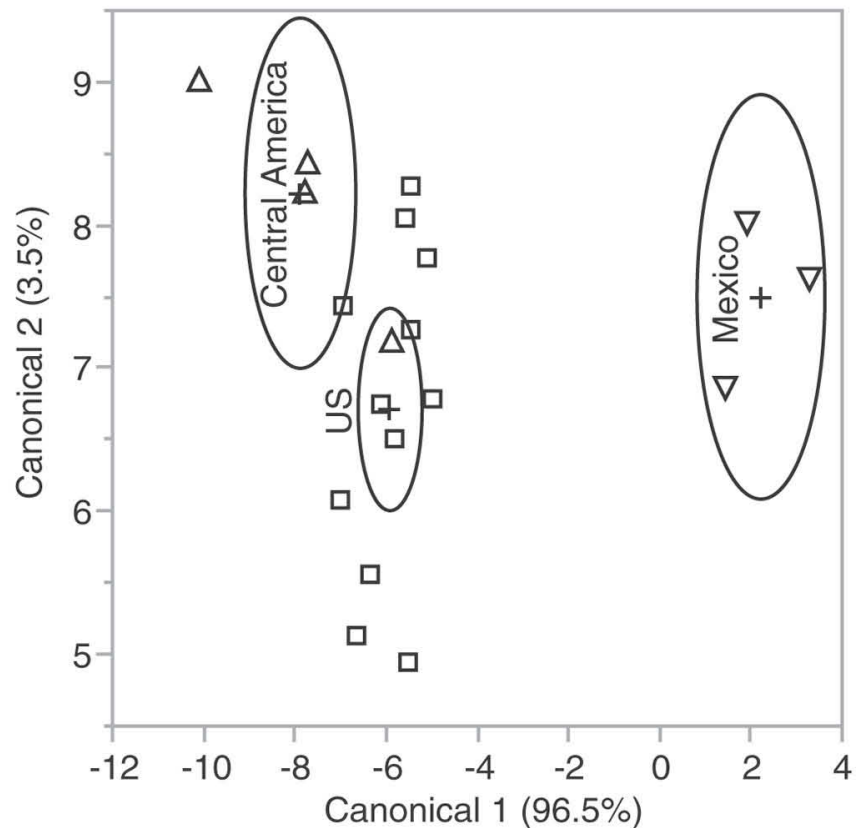

Hand Texture, Aged Cheese

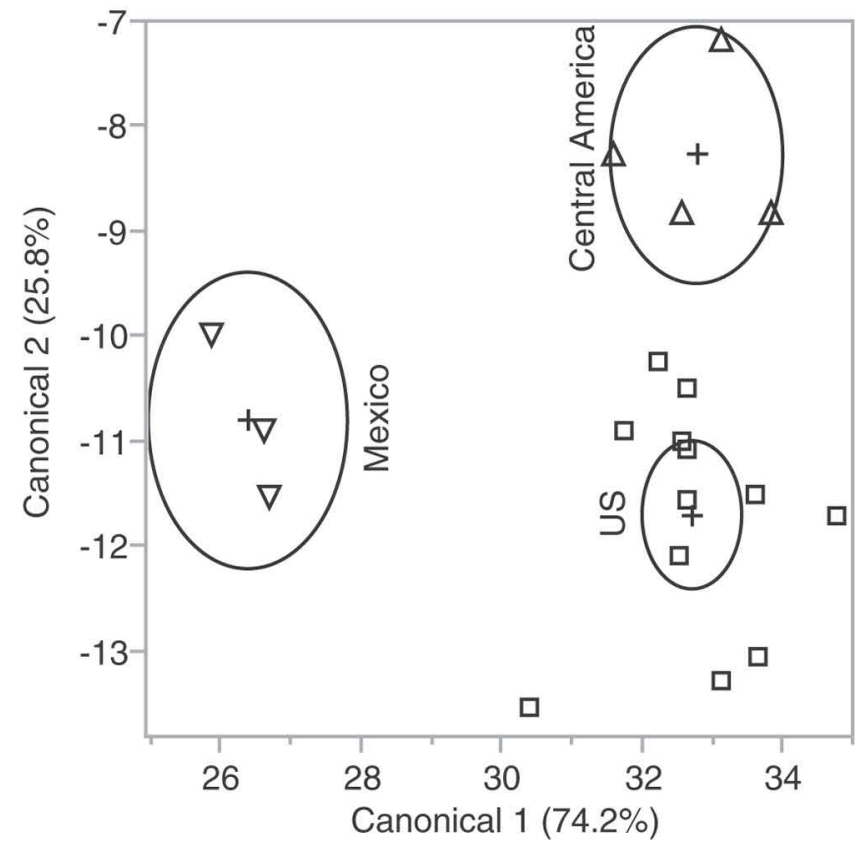

Flavor, Aged Cheese

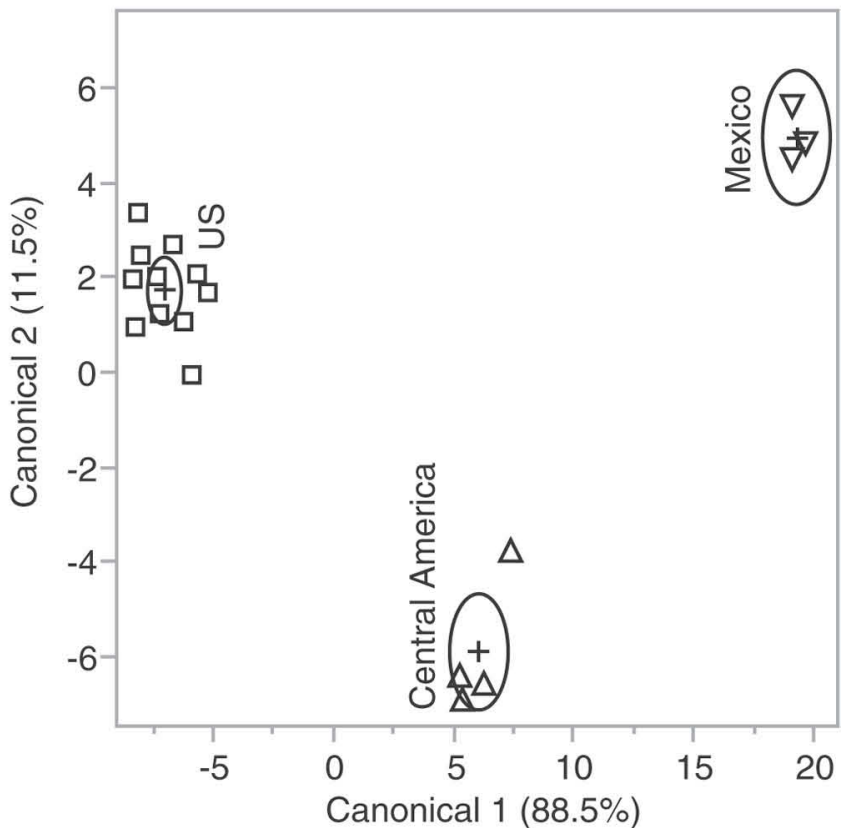

Figure 3. Canonical plots of aged Hispanic cheeses by region based on appearance, hand texture, mouth texture, and flavor attributes. The circles represent the $95 \%$ confidence region to contain the true mean of the region. Samples represented are Central America $(\Delta)$, Mexico $(\nabla)$, and the United States $(\square)$.

(FCHrd) would need to be increased. Finally, the flavor plot showed distinct separation of the ellipses for all regions, and the sensory data indicate that the US samples would need to have reduced acidity, whey, and milkfat notes, and increased bitterness, cowy/barny, yeast, soapy, and oxidized notes to be more similar to the Mexican samples. In contrast, they would need to have reduced whey notes and increased floral and oxidized notes to be more similar to the Central American samples. 


\section{CONCLUSIONS}

The analyzed fresh and pasta filata Hispanic cheeses made in the United States had chemical compositions, melt profiles, and sensory characteristics statistically indistinguishable from the same Hispanic cheeses made in Mexico. However, the large standard deviations observed in most analyses hinted at variation in USmade cheeses that strays from the results obtained in the country-of-origin samples, which could explain why some consumers of Hispanic cheese in the United States prefer imported over domestic cheeses. On the other hand, the analyzed aged Hispanic cheeses made in the United States had chemical compositions and melt profiles that matched those of Mexican aged cheeses, despite the presence of large standard deviations in the analyses that suggest the similarities are not always consistent. However, the sensory characteristics of the aged Hispanic cheeses manufactured in different regions differed considerably, with Mexican aged cheeses having textures and flavors that were very different from those of aged cheeses made in Central America, and US-made aged Hispanic cheeses having sensory characteristics unlike those of cheeses from the other 2 regions. Adjustments during manufacturing are needed so that US cheeses more closely match the texture and flavor profiles of the aged country-of-origin cheeses. Finally, the microbiological quality of all 3 types of Hispanic cheeses made in the United States was consistently superior to that of the cheeses made in their countries of origin.

\section{ACKNOWLEDGMENTS}

The authors of this work acknowledge the financial support of Dairy Management Inc. (Rosemont, IL), the Cheese and Industry Team (Madison, WI), and the Babcock Institute (Madison, WI). We thank the Wisconsin Center for Dairy Research (Madison, WI) for its invaluable technical assistance, the Monterrey Institute of Technology and Higher Education-Queretaro Campus (ITESM-CQ; Santiago de Quéretaro, Quéretaro, Mexico) and the Centro de Investigación en Alimentación y Desarrollo (CIAD; Hermosillo, Sonora, Mexico) for contributing with samples to this study.

\section{REFERENCES}

Andrews, W. H., and T. Hammack. 1998. Salmonella. Chapter 5. Pages 5.01-5.13 in Bacteriological Analytical Manual (BAM). AOAC, Arlington, VA.

AOAC International. 2000. Official Methods of Analysis. 17th ed. AOAC International, Gaithersburg, MD.
Bennett, R. W., and G. A. Lancette. 2001. Staphylococcus aureus. Chapter 12. Pages 12.01-12.05 in Bacteriological Analytical Manual (BAM). AOAC, Arlington, VA.

Brown, J. A., E. A. Foegeding, C. R. Daubert, M. Drake, and M. Gumpertz. 2003. Relationships among rheological and sensorial properties of young cheeses. J. Dairy Sci. 86:3054-3067. http:// dx.doi.org/10.3168/jds.S0022-0302(03)73905-8.

CCFRA. 1995. Microbiological Methods Manual. 2nd ed. Campden and Chorleywood Food Research Association, Chipping Campden, UK.

General de Normas, D. 1994. Bienes y Servicios. Quesos: Frescos, madurados y procesados. Especificaciones sanitarias. Diario Oficial de la Federación. Norma Oficial Mexicana NOM-121-SSA1-1994. Mexico City, Mexico.

Downes, F. P., and K. Ito. 2001. Compendium of Methods for the Examination of Foods. 4th ed. American Public Health Association, Washington, DC.

Drake, M., P. D. Gerard, and G. V. Civille. 1999. Ability of hand evaluation versus mouth evaluation to differentiate texture of cheese. J. Sens. Stud. 14:425-441. http://dx.doi.org/10.1111/j.1745459X.1999.tb00126.x.

Drake, M., S. C. McIngvale, P. D. Gerard, K. R. Cadwallader, and G. V. Civille. 2001. Development of a descriptive language for cheddar cheese. J. Food Sci. 66:1422-1427. http://dx.doi. org/10.1111/j.1365-2621.2001.tb15225.x.

Hitchins, A. D. 1998. Listeria monocytogenes. Chapter 10. Pages 10.01-10.13 in Bacteriological Analytical Manual (BAM). AOAC, Arlington, VA.

Hnosko, J., S. Clark, and D. L. Van Hekken. 2009. Latin American cheeses. Pages 489-504 in The Sensory Evaluation of Dairy Products. S. Clark, M. Costello, M. Drake, and F. Bodyfelt, ed. Springer, New York, NY.

Johnson, M. E., and N. F. Olson. 1985. A comparison of available methods for determining salt levels in cheese. J. Dairy Sci. 68:10201024. http://dx.doi.org/10.3168/jds.S0022-0302(85)80924-3.

Meilgaard, M. C., G. V. Civille, and B. T. Carr. 2007. Sensory Evaluation Techniques. 4th ed. M. Meilgaard, G. V. Civille, and B. T. Carr, ed. CRC Press, Boca Raton, FL.

Muthukumarappan, K. 2001. Evaluating cheese melt characteristics using cheese melt profile analysis. In 2001 ASAE Annu. Int. Mtg., Sacramento, CA. Am. Soc. Agric. Eng., St. Joseph, MI. $10.13031 / 2013.3588$.

Packaged Facts. 2012. Hispanic Foods and Beverages in the U.S. 5th ed. MarketResearch.com Inc., Rockville, MD.

Powers, J. J., and G. O. Ware. 1986. Discriminant analysis. Pages 125-180 in Statistical Procedures in Food Research. J. R. Piggott, ed. Elsevier Applied Science, New York, NY.

Tunick, M. H. 2007. Hispanic dairy products. Pages 33-43 in Hispanic Foods: Chemistry and Flavor (ACS Symposium Series Book 946). M. H. Tunick and E. González de Mejía, ed. American Chemical Society, Washington, DC.

US Census Bureau. 2012. The Hispanic population in the United States: 2012. Accessed Jan. 11, 2015. http://www.census.gov/ population/hispanic/data/2012.html.

USDA-NASS (National Agricultural Statistics Service). 2015. Dairy Products 2014: Summary. Accessed Jan. 6, 2015. http:// usda.mannlib.cornell.edu/MannUsda/viewDocumentInfo. do?documentID $=1054$.

Van Hekken, D. L., M. H. Tunick, P. M. Tomasula, F. J. M. Corral, and A. A. Gardea. 2007. Mexican Queso Chihuahua: Rheology of fresh cheese. Int. J. Dairy Technol. 60:5-12. http://dx.doi. org/10.1111/j.1471-0307.2007.00291.x.

Wehr, M. H., and J. F. Frank. 2004. Standard Methods for the Examination of Dairy Products. 17th ed. American Public Health Association, Washington, DC.

Wisconsin Milk Marketing Board. 2015. Cheese imports, exports and the US cheese supply. Accessed Sep. 29, 2015. http:// www.wmmb.com/cheese-companies/market-information/ completelisting?CatID $=7 ; 28$. 